\title{
Distribution of microglial cells in the cerebral hemispheres of embryonic and neonatal chicks
}

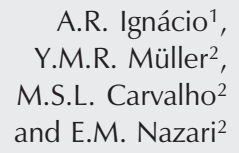

\author{
'Departamento de Ciências Biológicas, Instituto de Ciências Naturais e Tecnológicas, \\ Universidade Estadual do Mato Grosso, Cáceres, MT, Brasil \\ ${ }^{2}$ Departamento de Biologia Celular, Embriologia e Genética, Centro de Ciências \\ Biológicas, Universidade Federal de Santa Catarina, Florianópolis, SC, Brasil
}

\author{
Correspondence \\ Y.M.R. Müller \\ Laboratório de Reprodução e \\ Desenvolvimento Animal \\ BEG, CCB, UFSC \\ 88010-970 Florianópolis, SC \\ Brasil \\ Fax: +55-48-331-5148 \\ E-mail: yararm@ccb.ufsc.br \\ Presented at the XI Congresso \\ Brasileiro de Biologia Celular, \\ Campinas, SP, Brazil, July 15-18, \\ 2004.
}

Received July 16, 2004 Accepted May 10, 2005

\section{Abstract}

The distribution, morphology and morphometry of microglial cells in the chick cerebral hemispheres from embryonic day 4 (E4) to the first neonatal day (P1) were studied by histochemical labeling with a tomato (Lycopersicon esculentum) lectin. The histochemical analysis revealed lectin-reactive cells in the nervous parenchyma on day E4. Between E4 (5.7 $\pm 1.35 \mathrm{~mm}$ length) and E17 (8.25 $\pm 1.2 \mathrm{~mm}$ length), the lectin-reactive cells were identified as ameboid microglia and observed starting from the subventricular layer, distributed throughout the mantle layer and in the proximity of the blood vessels. After day E13, the lectin-reactive cells exhibited elongated forms with small branched processes, and were considered primitive ramified microglia. Later, between E18 (5.85 $\pm 1.5 \mathrm{~mm}$ cell body length) and P1 (3.25 $\pm 0.6 \mathrm{~mm}$ cell body length), cells with more elongated branched processes were observed, constituting the ramified microglia. Our findings provide additional information on the migration and differentiation of microglial cells, whose ramified form is observed at the end of embryonic development. The present paper focused on the arrangement of microglial cells in developing cerebral hemispheres of embryonic and neonatal chicks, which are little studied in the literature. Details of morphology, morphometry and spatial distribution of microglial cells contributed to the understanding of bird and mammal central nervous system ontogeny. Furthermore, the identification and localization of microglial cells during the normal development could be used as a morphological guide for embryonic brain injury researches.

\section{Introduction}

In birds, the cerebral hemispheres develop from the telencephalon by a process of evagination, and there is a gradual thickening of the telencephalic walls as neuroblasts migrate radially from the neuroepithelium lining the ventricular surface of the hemispheres (1). In chicks the cerebral hemi-
Key words

- Microglia

- Cerebral hemispheres

- Embryos

- Neonatal chicks

- Gallus domesticus

- Tomato lectin 
The complex organization of the nervous system has been shown to arise from cell proliferation and migration during early histogenesis. Structures in the telencephalon are identified in relatively mature chick brains at 16 days of embryonic development (3), and the histological features observed in the cerebral hemispheres of newly hatched chicks are similar to those seen in 24-dayold and adult chicks (2).

From the initial neurogenesis, the neurons become intimately related to the glial cells, which in the central nervous system (CNS) of vertebrates carry out specialized functions in close interaction with surrounding neurons and blood vessels (4). In 16day-old embryos the differentiation of neurons is sufficiently advanced to enable the distinction between neurons and glial cells by tritiated thymidine autoradiography $(5,6)$. The neurons, astrocytes and oligodendrocytes arise from the neuroectoderm (7); however, the origin of microglial cells is still controversial (8-10).

The presence of transiently ameboid cells is a typical feature in the developing CNS $(8,11)$. Del Río-Hortega (12) first referred to these ameboid cells as possible precursors of microglial cells, implying that the rounded ameboid cells were giving rise to more differentiated or ramified forms. It is well documented that microglial cells exhibit two different morphological forms: ameboid microglia, which exist transiently in the developing brain, and ramified microglia (13), which also occur in the perinatal brain and represent most of the microglia in the avian and mammalian adult brain (14).

The roles of microglia can be related to many of the complex morphogenetic and histogenetic processes occurring during CNS development to establish the complex network of connections present in the adult $(8,15)$. Besides promoting axonal growth, the microglia also exhibit phagocytic activities, specifically in the elimination of transitory or aberrant axons and the removal of apoptotic bodies, which are abundantly present in the normal developing CNS, and also promote axonal growth and stimulate the vascularization of the CNS $(7,8,10)$.

The distribution and morphology of microglial cells in the brain of mammalian and bird embryos and adults and in the optic nerve, retina and cerebellum have been studied with the aid of markers and histochemical procedures $(2,9)$. Specific labels, such as the lectins, are able to recognize the microglial phenotypes with greater precision (1620). The localization of reactive microglial cells during the normal development of the nervous system could be used as an accessory procedure for delineating areas of neurotoxicant-induced brain injury $(8,21)$.

The aim of the present study was to characterize the distribution and morphological and morphometric features of the microglial cells present in the developing cerebral hemispheres of embryos and neonatal chicks by labeling with the lectin Lycopersicon esculentum.

\section{Material and Methods}

Gallus domesticus eggs were incubated at a temperature of $38^{\circ} \mathrm{C}$ and $65 \%$ humidity. Seventy-six embryos were analyzed, ranging in age between the 4th embryonic day (E4) and the 1st neonatal day (P1). On each embryonic day, four embryos were desensitized and sacrificed, and the brains were quickly removed and fixed in $4 \%$ paraformaldehyde in $0.1 \mathrm{M}$ phosphate-buffered saline (PBS), $\mathrm{pH} \mathrm{7.4,} \mathrm{at} 4^{\circ} \mathrm{C}$ and then transferred to $30 \%$ sucrose in $0.1 \mathrm{M} \mathrm{PBS}$ at room temperature.

Brain tissue blocks were cut into 30- $\mu \mathrm{m}$ frozen sections and pre-incubated with $2 \%$ $\mathrm{H}_{2} \mathrm{O}_{2}$ in methanol for 15 min to block endogenous peroxidase reactivity, before being washed twice in 0.1 M PBS and once in PBS with Triton X-100. Serial sections were then incubated overnight with L. esculentum lectin $(6 \mu \mathrm{g} / \mathrm{ml}$ in PBS $)$ conjugated with biotin 
(Sigma, St. Louis, MO, USA) at $4^{\circ} \mathrm{C}$. Sections were then incubated with the avidinperoxidase complex (Sigma) for $1 \mathrm{~h}$ at room temperature and washed three times in PBS. The reaction was visualized by application of a 3,3'-diaminobenzidine solution $(1 \mathrm{mg} /$ $\mathrm{ml}$; Sigma) and $\mathrm{H}_{2} \mathrm{O}_{2}(1 \mathrm{ml} / 60 \mu \mathrm{l})$, before counterstaining with Harris' hematoxylin. Sections of E7 (4 embryos) and E18 (4 embryos) were incubated without lectin as a negative control.

In this study, the labeled microglial cells were classified into three groups: ameboid cells, primitive ramified cells, and ramified cells (22). The regions of the cerebral hemispheres were described according to a new terminology for the avian telencephalon (23).

Morphometric analysis of microglial cells was performed by cell diameter measurement using a light microscope with an eyepiece scale (10X). The diameter of microglial cells was obtained from the average of the longitudinal and transverse axes. From E18 to P1 the cellular processes were also measured. The number of cells needed to establish the average size was determined by the equation $\mathrm{n}=1.96 \mathrm{~s} / \mathrm{l}$, where $\mathrm{s}=$ standard deviation of the first five cell measurements and $1=10 \%$ of the first average (24).

Stereological analysis of the sections was performed with the Weibel graticule (40X) (25) to determine the percentage of microglial cells. The number of these cells was obtained in five random visual fields, in which 42 cells were counted in each field to give a total of 210 cells in each section. The frequency of microglial cells was taken as a percentage of the total number of cells $(\mathrm{N}=$ 210).

\section{Results}

Serial sections of the cerebral hemispheres of chick embryos between the ages of E4 and P1 were analyzed and lectinlabeled microglial cells were identified. Figure 1 shows in rostral and intermediate sec- tions the main locations of lectin-reactive cells at three representative developmental ages. The microglial cells showed a diversity of shape and size (Table 1) and were distributed in the different areas of the cerebral hemispheres (Table 2).

In $\mathrm{E} 4$ embryos the cerebral hemispheres presented walls of uniform thickness, and labeled ameboid cells were observed mainly in the leptomeninges and in the CNS parenchyma. At E5 the hemisphere walls were
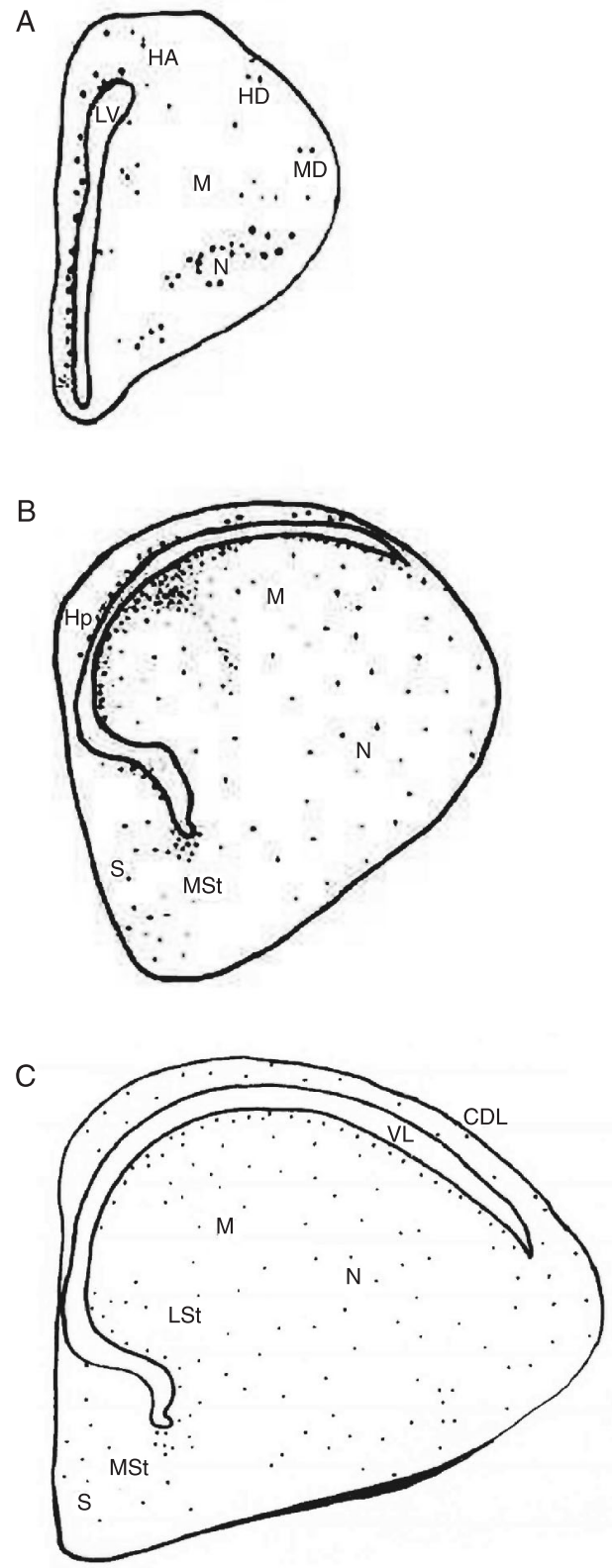

Figure 1. Schematic drawing of coronal sections of the chick embryo telencephalon showing the location of lectin-reactive cells (points). $A,(\mathrm{E} 7)$ rostral section; $B,(\mathrm{E} 12) ; C,(\mathrm{P} 1)$ intermediate section. $\mathrm{CDL}=$ dorsolateral corticoid area; $\mathrm{HA}=$ apical part of the hyperpallium; $\mathrm{HD}=$ densocellular part of the hyperpallium; $\mathrm{Hp}=$ hippocampus; LV = lateral ventricle; $\mathrm{LSt}=$ lateral striatum; $\mathrm{M}=$ mesopallium; $\mathrm{MD}=$ dorsal mesopallium; $\mathrm{MSt}=\mathrm{me}-$ dial striatum; $N=$ nidopallium; $S=$ septum. Scale bar $=200 \mu \mathrm{m}$. 
enlarged in all directions and the ventricular layer could be recognized. There was a marked increase in the number of microglial ameboid cells at this age, distributed throughout the ventricular layer and in close approximation to blood vessels (Figure 2A). From E5 to E8 there was no increase in the number of ameboid microglial cells. At E9 there was a decrease in the number of ameboid cells (Figure 2B), and after E18 these cells were no longer observed (Figure 3).

In the subventricular layer and dorsal pallial structures a large number of lectinreactive cells were observed, when compared to the apical part of the hyperpallium and mesopallium region. After E9, an increase in labeled cells was identified in the area of the striatum. Primitive ramified microglial cells (Figure 2C) were recognized in the subventricular layer and in the hypopallium, mesopallium and nidopallium regions in embryos between E13 and E20. The primitive microglial cells have a large cell body

\begin{tabular}{|c|c|c|c|}
\hline & $\begin{array}{l}\text { Diameter of } \\
\text { microglial cells }(\mu \mathrm{m})\end{array}$ & $\begin{array}{l}\text { Size of branched } \\
\text { process }(\mu \mathrm{m})\end{array}$ & $\begin{array}{c}\text { Total number o } \\
\text { cells counted }\end{array}$ \\
\hline \multicolumn{4}{|c|}{ Ameboid cells } \\
\hline E4 & $5.7 \pm 1.35$ & - & 8 \\
\hline E5 & $7.1 \pm 1.5$ & - & 20 \\
\hline E6 & $6.85 \pm 1.2$ & - & 20 \\
\hline E7 & $7.1 \pm 1.0$ & - & 46 \\
\hline E8 & $6.2 \pm 0.95$ & - & 45 \\
\hline E9 & $5.95 \pm 0.5$ & - & 33 \\
\hline E10 & $6.6 \pm 1.55$ & - & 36 \\
\hline E11 & $8.95 \pm 1.1$ & - & 30 \\
\hline E12 & $9.7 \pm 1.1$ & - & 29 \\
\hline E13 & $8.9 \pm 1.1$ & - & 34 \\
\hline E14 & $10.45 \pm 1.7$ & - & 29 \\
\hline E15 & $7.45 \pm 1.0$ & - & 27 \\
\hline E16 & $7.85 \pm 0.8$ & - & 27 \\
\hline E17 & $8.25 \pm 1.2$ & - & 23 \\
\hline \multicolumn{4}{|c|}{ Ramified cells } \\
\hline E18 & $5.85 \pm 1.5$ & $11.5 \pm 6.55$ & 21 \\
\hline E19 & $4.7 \pm 0.95$ & $9.3 \pm 1.85$ & 14 \\
\hline E20 & $4.7 \pm 0.9$ & $8.55 \pm 2.2$ & 20 \\
\hline E21 & $4.15 \pm 0.75$ & $8.15 \pm 2.1$ & 13 \\
\hline $\mathrm{P} 1$ & $3.25 \pm 0.6$ & $4.75 \pm 2.25$ & 13 \\
\hline
\end{tabular}

with a short process. Some cell clusters were visualized towards the dorsal pallial region.

During the period between E18 and E21 the first ramified microglial cells (Figure 2D) with long processes (Table 1) were observed mainly in the dorsal pallial region, although these were also present in the subventricular layer and meningeal tissue. After hatching (P1), only the ramified microglia were labeled, with most of the cells distributed in the area of the nidopallium, mesopallium, dorsal corticoid area, from the subventricular layer and pial surface to the area of the lateral striatum and medial striatum, where there was a smaller number of microglial cells.

\section{Discussion}

In the present study, microglial cells displayed intense labeling with $L$. esculentum lectin and during the CNS development of G. domesticus ameboid microglia, primitive ramified microglia and ramified microglia were all identified. These results are similar to those described for the quail cerebellum and for the cerebral hemispheres of chick embryos and chicks $(2,26)$.

The distribution of the ameboid microglial cells in the subventricular layer suggests that these cells are the microglial precursors, since they are present from the earliest ages studied and they morphologically resemble the cells described for the cerebral hemispheres of chick embryos and chicks $(2,9)$.

During development, the distribution of microglial cells probably depends on the functions that they perform, but this distribution may be a consequence of their migration to their final locations in the adult CNS. This is similar to the situation in neuroblasts, which play no specific role before they reach their final location (7).

The temporal-spatial distribution of lectin-reactive cells observed here shows that the microglial cells are present in the cere- 
Table 2. Distribution and lifespan of microglial cells in different areas of the cerebral hemispheres of chick embryos and neonatal chicks

\begin{tabular}{|c|c|c|c|}
\hline \multirow{2}{*}{$\begin{array}{l}\text { Embryonic } \\
\text { day }\end{array}$} & \multicolumn{3}{|c|}{ Categories of microglial cells } \\
\hline & Ameboid & Primitive ramified & Ramified \\
\hline E4 & CNS parenchyma and leptomeninges & - & - \\
\hline E5 & Ventricular layer & - & - \\
\hline E6-E9 & Subventricular and dorsal pallial structures & - & - \\
\hline E10 & $\begin{array}{l}\text { Subventricular layer and region next to the } \\
\text { blood vessels in the pallial regions }\end{array}$ & - & - \\
\hline E11 & Subventricular layer and pallial regions & - & - \\
\hline E12 & Subventricular layer and pallial regions & - & - \\
\hline E13 & $\begin{array}{l}\text { Subventricular layer, nidopallium, } \\
\text { mesopallium, and dorsal mesopallium }\end{array}$ & $\begin{array}{l}\text { Subventricular layer, nidopallium, } \\
\text { mesopallium, and dorsal mesopallium }\end{array}$ & - \\
\hline E14-E16 & $\begin{array}{l}\text { Nidopallium, mesopallium and } \\
\text { hyperpallium regions }\end{array}$ & $\begin{array}{l}\text { Nidopallium, mesopallium, and } \\
\text { hyperpallium regions }\end{array}$ & - \\
\hline E17-E18 & $\begin{array}{l}\text { Subventricular layer and mesopallium and } \\
\text { hyperpallium regions }\end{array}$ & $\begin{array}{l}\text { Uniformly distributed in the pallium and } \\
\text { striatum regions }\end{array}$ & $\begin{array}{l}\text { Subventricular layer, pallium and } \\
\text { striatum }\end{array}$ \\
\hline E19 & - & Dorsal pallial region and striatum regions & $\begin{array}{l}\text { Dorsal pallial region, medial striatum } \\
\text { and lateral striatum }\end{array}$ \\
\hline E20-E21 & - & Dorsal corticoid area & $\begin{array}{l}\text { Striatum regions, subventricular layer } \\
\text { and in parallel to the choroid plexus of } \\
\text { the lateral ventricles }\end{array}$ \\
\hline P1 & - & - & $\begin{array}{l}\text { Nidopallium, mesopallium dorsal } \\
\text { corticoidea area and some cells } \\
\text { dispersed in the striatum regions }\end{array}$ \\
\hline
\end{tabular}

A

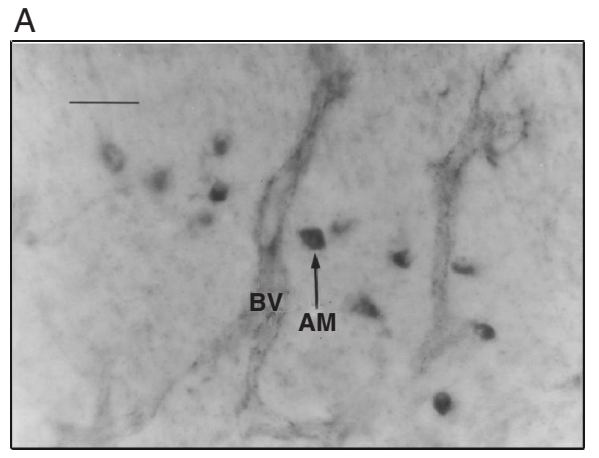

C

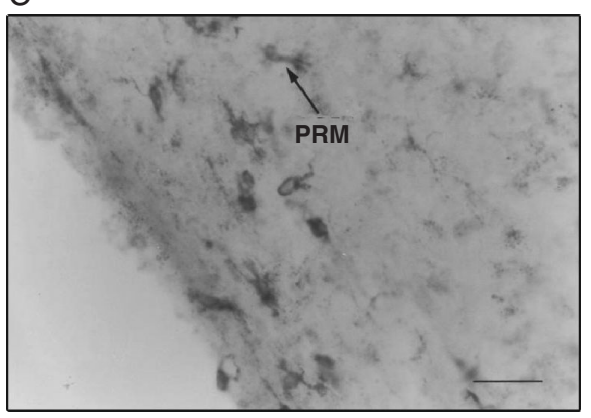

B

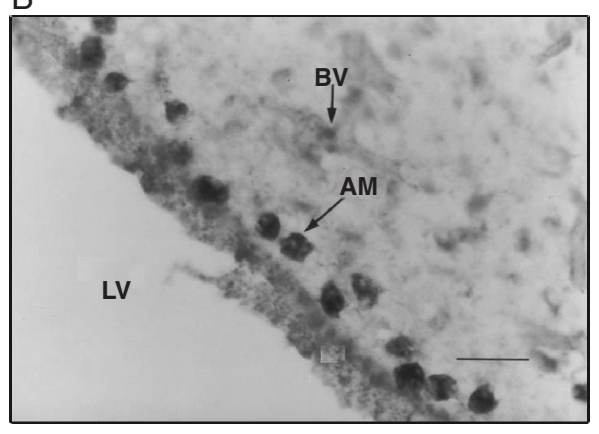

$\mathrm{D}$

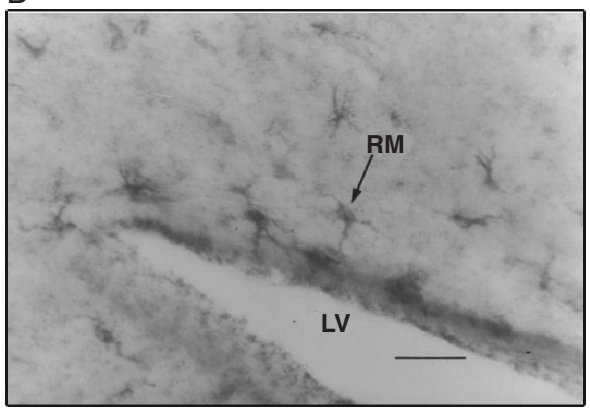

Figure 2. Coronal sections of the cerebral hemispheres of chick embryos of different ages ( $A$, E5; $B, \mathrm{E} 12 ; C$, E19; $D$, E19) showing lectin-reactive cells. $L V=$ lateral ventricle; $\mathrm{AM}=$ ameboid microglial cell; PRM = primitive ramified microglial cell; $\mathrm{RM}=$ ramified microglial cell; $\mathrm{BV}=$ blood vessel. Scale bars: $A, B, C=22 \mu \mathrm{m} ; \mathrm{D}=10 \mu \mathrm{m}$. 
Figure 3. Ameboid, primitive ramified and ramified microglial cell percentage from embryonic day 4 (E4) to embryonic day 21 (E21) embryos and the first neonatal day (P1) chicks.

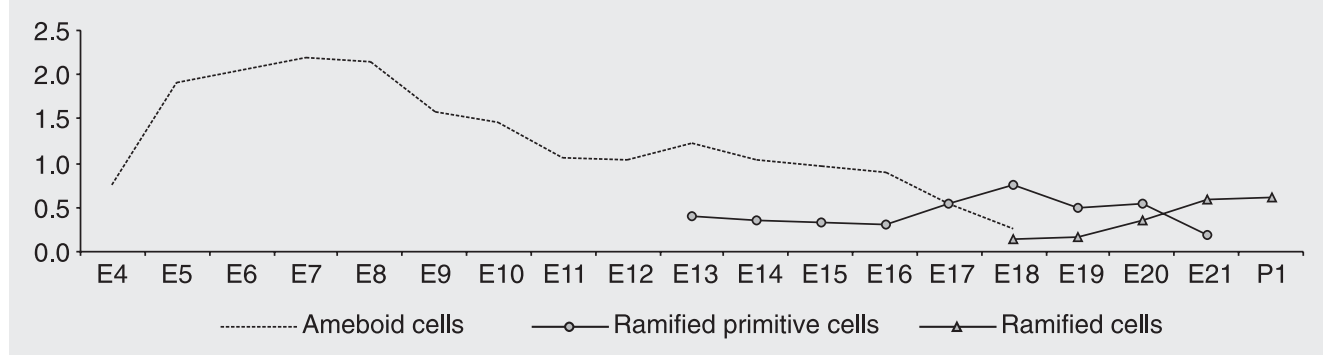

bral hemispheres from early neurogenesis and tend to increase in number during CNS differentiation. These observations corroborate the hypothesis presented by others (10) and are compatible with the descriptions of different areas of the CNS including the quail cerebellum (26), quail retina (22) and the prenatal rat hippocampus (27). Microglia constitute a significant part of the glial cell population, between 5 and $12 \%$ of the total number of CNS cells (28), and are distributed unevenly in the regions of the CNS $(29,30)$. Our data show the percentage of microglial cells in a particular area of the chick CNS, the cerebral hemispheres, that explains the lower percentage of microglial cells present in Figure 3 compared to the literature.

During development, the differentiation of the ameboid lectin-reactive cells into primitive ramified and ramified microglia suggests that these cells may belong to a single glial population, and that during neurogenesis they develop into morphologically distinct types characterized by a decreased volume of the cell body, a decrease in the number of vacuoles and the growth of processes leading to the final differentiated, resident ramified form $(2,9,27)$.
Therefore, our results suggest that in the cerebral hemispheres apparently not all the ameboid cells develop into ramified resident microglia (Figure 2). Other studies $(2,27)$ have shown that many ameboid cells carry out a phagocytic function and in specific conditions in the neuronal environment they can undergo cell death. Other cells can reach the immature stage, characterized by the poorly ramified microglia form and they can be activated by adverse conditions to the nervous system, returning to the phagocytic form. Only a part of the microglial precursor population would pass through all the stages reaching the mature ramified form during the late embryonic development and the initial postnatal phase, a hypothesis supported by the small number of ramified lectin-reactive cells in comparison to ameboid cells.

Microglial cells are considered to be the most plastic cell population in the CNS and exhibit a primordial activity in normal embryonic development and adult brain function. They have also assumed an important role in various neurodegenerative diseases and neurological disorders (31) and this will be the focus of study in microglia research in the next decades.

\section{References}

1. Ulinski PS \& Margoliash D (1990). Neurobiology of the reptile-bird transition. In: Jones EG \& Peters A (Editors), Cerebral Cortex. Plenum Press, New York, 217-265.

2. Fujimoto E, Miki A \& Mizoguti $H$ (1987). Histochemical studies of the differentiation of microglia cells in the cerebral hemispheres of chick embryos and chicks. Histochemistry, 87: 209-216.
3. Kallen B (1962). Embryogenesis of brain nuclei in the chick telencephalon. Ergebnisse Anatomie Entwicklung Geschichte, 36: 6282.

4. Gerhard H, Schuck J \& Wolburg H (1999). Differentiation of a unique microglial cell type in the pectin oculi of the chicken. Glia, 28: 201214. 
5. Tsai HM, Garber BB \& Larramendi MH (1981). ${ }^{3} \mathrm{H}$-Thymidine autoradiographic analysis of telencephalic histogenesis in the chick embryo: I. Neuronal birthdates of telencephalic compartments in situ. Journal of Comparative Neurology, 198: 275-292.

6. Tsai HM, Garber BB \& Larramendi MH (1981). ${ }^{3} \mathrm{H}$-Thymidine autoradiographic analysis of telencephalic histogenesis in the chick embryo: II. Dynamics of neuronal migration, displacement, and aggregation. Journal of Comparative Neurology, 198: 293-306.

7. Cuadros MA \& Navascués $J$ (1998). The origin and differentiation of microglial cells during development. Progress in Neurobiology, 56: 173-189.

8. Streit WJ (2001). Microglia and macrophages in the developing CNS. Neurotoxicology, 22: 619-624.

9. Kaur C, Hao AJ, Wu CH et al. (2001). Origin of microglia. Microscopy Research and Technique, 54: 2-9.

10. Navascués J, Calvente R, Marin-Teva JL et al. (2000). Entry, dispersion and differentiation of microglia in the developing central nervous system. Anais da Academia Brasileira de Ciências, 72: 91102.

11. Fujimoto E, Miki A \& Mizoguti H (1989). Histochemical study of the differentiation of microglial cells in the developing human cerebral hemispheres. Journal of Anatomy, 166: 253-264.

12. Del Río-Hortega P (1932). Microglia. In: Penfield W (Editor), Cytology and Cellular Pathology of the Nervous System. Paul B. Hoeber, New York, 482-534.

13. Nakajima K \& Kosaka S (1993). Functional roles of microglia in the brain. Neuroscience Research, 17: 187-203.

14. Ling EA \& Wong WC (1993). The origin and nature of ramified and ameboid microglia: a historical review and current concepts. Glia, 7: 9-18.

15. Ferrer I, Bernet E, Soriano E et al. (1990). Naturally occurring cell death in the cerebral cortex of the rat and removal of dead cells by transitory phagocytes. Neuroscience, 39: 451-458.

16. Acarin L, Vela JM, González B et al. (1994). Demonstration of poly$\mathrm{N}$-acetyl lactosamine residues in ameboid and ramified microglial cells in rat brain by tomato lectin binding. Journal of Histochemistry and Cytochemistry, 42: 1033-1041.

17. Barradas PC \& Cavalcante LA (1998). Proliferation of differentiated glial cells in the brain stem. Brazilian Journal of Medical and Biological Research, 31: 257-270.
18. Boya J, Calvo JL, Carbonell AL et al. (1991). A lectin histochemistry study on the development of rat microglial cells. Journal of Anatomy, 175: 229-236.

19. Boya J, Carbonell AL, Calvo JL et al. (1991). Microglial cells in the nervous system of the rabbit and rat: cytochemical identification of two different lectins. Acta Anatomica, 140: 250-253.

20. Cavalcante LA, Santoro GF, Barradas PC et al. (1995). Lectin histochemistry of microglia in superior colliculus of the developing opossum. Ciência e Cultura, 4: 240-245.

21. Aschner M, Allen JW, Kimelberg HK et al. (1999). Glial cells in neurotoxicity development. Annual Review of Pharmacology and Toxicology, 39: 151-173.

22. Navascués J, Moujahid A, Almendros A et al. (1995). Origin of microglia in the quail retina: central-to-peripheral and vitreal-toscleral migration of microglial precursors during development. Journal of Comparative Neurology, 354: 209-228.

23. Reiner A, Perkel DJ, Bruce LL et al. (2004). Revised nomenclature for avian telencephalon and some related brainstem nuclei. Journal of Comparative Neurology, 473: 377-414.

24. Bussab WO \& Morettin PA (2004). Estatística Básica. Editora Saraiva, São Paulo, SP, Brazil.

25. Freere RH \& Weibel ER (1967). Stereologic techniques in microscopy. Journal of the Royal Microscopical Society, 87: 25-34.

26. Cuadros MA, Rodríguez-Ruiz J, Valvente R et al. (1997). Microglia development in the quail cerebellum. Journal of Comparative Neurology, 389: 390-401.

27. Dalmau I, Finsen B, Tonder N et al. (1997). Development of microglia in the prenatal rat hippocampus. Journal of Comparative Neurology, 377: 70-84.

28. Fedoroff S (1995). Development of microglia. In: Kettenmann H \& Ransom BR (Editors), Neuroglia. Oxford University Press, New York, 162-181.

29. Lawson LJ, Perry VH, Dri P et al. (1990). Heterogeneity in the distribution and morphology of microglia in the normal adult mouse brain. Neuroscience, 39: 151-170.

30. Cuadros MA \& Navascués J (2001). Early origin and colonization of the developing central nervous system by microglial precursors. Progress in Brain Research, 132: 51-59.

31. Schenk DB \& Yednock T (2002). The role of microglia in Alzheimer's disease: friend or foe? Neurobiology of Aging, 5: 677-679. 